\title{
A Study of Spectrum Valuation Methods in Telecommunication Services
}

\author{
Settapong Malisuwan, Noppadol Tiamnara, and Nattakit Suriyakrai
}

\begin{abstract}
At present day, due to the exponential demand for services such as mobile that requires spectrum, the demand of spectrum has become exceedingly high. Hence, regulators worldwide are faced with a big challenge to ensure sufficient spectrum supply to services that provide the most economic value. Therefore, studies on telecommunication service spectrum valuation have become increasingly more important than ever before. From literature review on the spectrum valuation studies from international experts, we can categorize the studies into two groups. The first values spectrum by opportunity cost approach, which compares the cost and revenue of bidders with and without spectrum. The second group of studies applies econometrics to data collected from past auctions in different countries as a guideline in spectrum valuation for studied country. It starts by using statistical technique to estimate regression model in order to find the relationship between actual auction prices in different countries and its determinants. Then, it forecasts the spectrum price for studied country by replacing the values of determinants in the equation. In practice, one might choose one or use both valuation methods in parallel as a cross-check. This paper will explore both groups of spectrum valuation methods.
\end{abstract}

Index Terms-Spectrum auction, license, reserve price.

\section{INTRODUCTION}

In the past decade we have seen the proliferation of internet devices and the rapid development of the information and communication technologies (ICT) more than ever before. This has lead to a paradigm shift and exponential increase in value of spectrum. Therefore, the management of spectrum has been undergoing a substantial evolution [1]. The industry and regulator have started to view spectrum as a scarce resource and in economic terms. The idea to view spectrum in economic terms is justified as it is the fundamental resource required as an input in the rapidly growing mobile service industry. This has resulted in telecoms regulator worldwide having to answer questions on how much spectrum is worth [1]. This is particularly crucial when the main method for spectrum assignment is by auction. The purpose of this research is to provide a detailed comparison of different types of spectrum valuation methods in order to evaluation the best option on a case by case basis.

Manuscript received May 7, 2015; revised July 21, 2015. This paper is supported by National Broadcasting and Telecommunications Commission in Thailand.

S. Malisuwan, N. Tiamnara, and N. Suriyakrai are with National Broadcasting and Telecommunications Commission Bangkok, Thailand (e-mail: settapong.m@nbtc.go.th, noppadol.m@nbtc.go.th, nattakit.s@nbtc.go.th).

\section{STUDIES OF SPECTRUM VALUATION BY OPPORTUNITY COST APPROACH}

An important step in spectrum valuation by opportunity cost approach is to analyze the proper representative of bidders which can be either a major operator in the market or an average firm [2]. The data required for spectrum valuation by opportunity cost approach include bidder's business and existing network engineering data as well as information on technologies that the operator might deploy [1], [2]. The opportunity cost calculation can be done by two main methods: cost reduction value and discounted cash flow.

To calculate the opportunity cost by cost reduction value, [2] suggests making an assumption that the number of subscribers and revenue in pre- and post-auction scenarios remain the same, but the new spectrum acquired from an auction will lower the cost of service provision. Therefore, the opportunity cost in this case is the net value of cost reduction created by the new spectrum throughout the license period. The cost reduction value analysis does not require data on bidders' revenue. Thus, it is easier to collect data and calculate the opportunity cost. The calculation of opportunity cost by discount cash flow value uses the data on costs and revenues. The studies by [3] states that if the revenue increases in accordance with the rise in the number of users and traffic in telecommunication market, the opportunity cost will be equal to the net present value of the cash flow or net revenue (income minus expense) throughout the license period. The spectrum valuation by this method might have errors in the forecasted income due to the uncertainty of income during license period. In addition, the spectrum price estimated by discounted cash flow value might be higher than the estimates from cost reduction value because of the assumption that the spectrum recipients will have opportunity to expand their business in the future. Plum Consulting (2011) studied and compared the actual spectrum value from the past auctions in various countries and found that the actual spectrum value usually lies between the cost reduction value and the discounted cash flow value [2]. This implies that, in most auctions, bidders could not accurately forecast their future revenues and costs of service provision.

The past literature found that when the economic trend is good and demand is higher than supply, the opportunity cost approach by cost reduction value yields estimates significantly lower than the actual values. For example, in this research [4], which studied the value of each operator in different regions of Sweden in 2002 using the methodologies above, found that the spectrum values were 0.8 to 4.3 Euro/MHz/pop with the median of around 3.3 Euro/MHz/pop [5]. However, the actual auction values range from 0.30 to 0.80 Euro/MHz/pop, which means that the engineering value is much lower than the actual auction price (1.5 to 10 times 
lower).

A study by [6] gives three reasons why actual auction price is much lower than spectrum value: (1) an attempt to prevent existing operators with spectrum holding from participating in the auction by using spectrum caps, (2) competition in the market; data from the past auctions in the United States reflected that the concentration ratio $(\mathrm{CR})$ rises along with the spectrum caps, although the increase in $\mathrm{CR}$ implies lower competition, and (3) spectrum-sharing policy for public benefit and infrastructure sharing between operators are a growing trend and thus lead to lower cost per MHz/pop [5], [7].

Bazelon (2011) studied the difference between spectrum value of $1690 \mathrm{MHz}$ and $1755 \mathrm{MHz}$ (AWS-3) to estimate cost and value of spectrum usage, or the net profit throughout the license period, which is comparable to the economic rent of license [3], [7]. The study found that the value of a license for the standard spectrum range that have more compatible equipment will have lower costs and larger scope of use, leading to significantly higher value than other spectrum bands. In addition, value of paired spectrum licenses have increased by 1.67 times higher than value of unpaired because the paired spectrum allows operators to send and receive signals separately resulting in better service quality. The spectrum valuation in the United States in 2011 (SpecEx Spectrum Index) found that the paired $2.1 \mathrm{GHz}$ spectrum (AWS-1) is valued at $\$ 1.05 / \mathrm{MHz} /$ pop.

This research [4] suggests another spectrum valuation for license renewal of sub- $1 \mathrm{GHz}$ spectrum for providing $3 \mathrm{G}$ and LTE (4G) services in Australia [5]. Plum Consulting (2011b) analyzed data from various countries prior to 2011 and found that the benchmark value for $900 \mathrm{MHz}$ spectrum auction range from $\$ 0.5 / \mathrm{MHz} /$ pop to $\$ 1.2 / \mathrm{MHz} /$ pop.

Plum Consulting (2011b) used business value method to find the range of spectrum value. It uses the projected cost as the minimum value and the enterprise value as the maximum value. The study finds that sub-1GHz spectrum has higher value than those above $1 \mathrm{GHz}$ for approximately 6.8 times, and finds that the grow in the average revenue per unit (ARPU) is an important factor in calculating spectrum value [5].

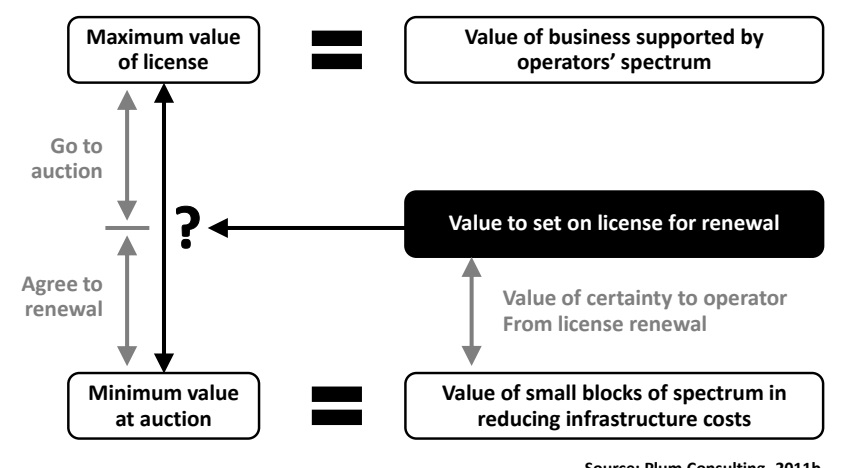

Fig. 1. Range of spectrum value. service at a higher price. At the same time, the government wants at least three operators in the market to avoid market concentration. Otherwise, the government should not renew the licenses and auction the licenses instead [5]. Thus, the spectrum price should not be higher than the marginal operator's estimated price to keep all operators in the market. Plum Consulting (2011b) used this concept to choose a proper value from the estimated range as shown in Fig. 1. If spectrum value is for use in auction, the concept mentioned above should be applied and the maximum value from full enterprise value should be considered to calculate the auction reserve price.

In addition, [8] studied valuation of commercial spectrum purchase in the United Kingdom using commercial and engineering models. The conceptual framework of Marks et al. (2009) [8] was that the spectrum value wad estimated with two factors: (1) cost reduction of existing service: the cost reduction can be a result of newer and more efficient technology than the existing one and (2) increase in revenue from new services after receiving the license: examples are data service and internet television.

From the two main factors, the more specific factors are revenue and cost drivers. Revenue drivers: revenue depends on the service demand which is determined by many economic variables such as service price, revenue, competition from similar service in the market. In practice, revenue will be forecasted by the expected ARPU growth rate, the number of users, ARPU determinants. Cost drivers: the costs of service provision include the network infrastructure, marketing, and management costs. The key cost relevant to spectrum value is the network infrastructure cost.

From the main cost and revenue concepts, the research by [8] estimated spectrum value by dividing the model into two parts: a service provision model used for revenue forecast and an engineering model used to forecast the cost change from the new technology. In sum, the research uses various variables to estimate model parameters as shown in Table I.

TABLE I: VARIABLES USED AS THE MODEL PARAMETERS [6]

\begin{tabular}{l|l}
\hline \hline Parameter related to market conditions & Parameter related to cost \\
\hline Population and growth rate & Spectrum frequency \\
\hline Penetration rate & Existing spectrum holding \\
\hline Number of operators & Cell site coverage \\
\hline Market share of each operator & Power of each cell site \\
\hline ARPU & Price of site establishment \\
\hline Voice traffic per person & Backhaul price \\
\hline Growth rate of voice traffic per person & Core network costs \\
\hline Data traffic per person & Trend of equipment costs \\
\hline Growth rate of data traffic per person & Network maintenance costs \\
\hline Ratio of coverage to total population & Site rental cost \\
\hline Interest payment & $\begin{array}{l}\text { Marketing cost } \\
\text { Management cost } \\
\text { Content costs }\end{array}$ \\
\hline \hline
\end{tabular}

\section{STUdIES OF SPECTRUM VALUATION BY ECONOMETRICS}

The second spectrum valuation approach is to use econometric method in finding the relationship between spectrum price from real auctions in different countries (auction price) and its determinants. Spectrum valuation by econometrics is easier than the opportunity cost approach as 
an econometric model needs macro-level data which are usually public. In contrast, the calculation of opportunity costs needs micro-level data including engineering, technology and business data which are usually confidential.

Spectrum valuation by econometrics can be done in three main steps: (1) the first step is to apply econometric concept to develop a model to explain spectrum value in different countries. Such model is derived by finding important determinants of spectrum value and then constructing a regression equation to show the relationship between spectrum value and its determinants; (2) the second step utilizes statistical methods to estimate the model and; (3) the last step is to predict spectrum value of the studied country by replacing its values of determinants into the estimated equation.

The model estimation is carried out by statistical and mathematical techniques. Popular statistical methods include (1) ordinary least squares estimation which is applied with standard models and (2) maximum likelihood estimation which is used in estimating a censored regression model. The next section will survey studies on spectrum valuation by these two techniques.

\section{A. Spectrum Valuation by Ordinary Least Squares}

A useful reference of spectrum valuation by ordinary least squares is Hazlett (2004), who studied spectrum auctions for 1,438 licenses from 42 auctions in 27 different countries since 1990. It classified important demand- and supply-side factors that influence license value as shown in Table II. The main factors consists of mobile phone industry structure, equipment costs, auction type and mechanism as well as license characteristics [9].

The research by [9] finds that, overall, independent variables in Table II can significantly explain the license value, except the number of population squared, the license period and the dummy for $800 \mathrm{MHz}$ or $900 \mathrm{MHz}$.

Competition level of telecommunication market has a significant effect on the spectrum value. Therefore it can be argued that when competition in the domestic telecommunication market is strong (lower HHI), the spectrum price will decrease.

Income per capita is a factor that has a direct impact on the license value because higher income raises operator's expectation on profits and it in turn lead to more aggressive bidding in the auction.

Quality of service as represented by the size of spectrum (WIDTH) also has a direct impact on the spectrum value since a larger spectrum bandwidth enables operators to increase the quality of service without additional investment. This results in higher profit and spectrum value.

Economies of scale reduce spectrum value. This research [9] used three variables as proxies for economies of scale: population, urbanization and population density. Population and urbanization are both significantly and positively correlated with the spectrum value. If a country becomes more populated and urbanized, the telecommunication market expansion will increase operator's income while the fixed cost per unit decreases. The spectrum value hence increases along with the profit. However, the population density has an opposite impact on spectrum value because of, as [9] argued, a multicollinearity problem between population density and urbanization [9].

TABLE II: DETERMINANTS OF SPECTRUM VALUE IN [11]

\begin{tabular}{|c|c|}
\hline Variable & Description \\
\hline$P_{i j t}$ & $\begin{array}{l}\text { License value for license } i \text { in an auction in country } j \text { at time } \\
t \text { (price/MHz/pop) }\end{array}$ \\
\hline$H H I_{i}$ & $\begin{array}{l}\text { Herfindahl-hirschman Index used to measure competition } \\
\text { level in mobile service }\end{array}$ \\
\hline$G N P P C_{i}$ & Income per capita \\
\hline $\mathrm{WIDTH}_{i}$ & Size of spectrum license $i(\mathrm{MHz})$ \\
\hline$P O P_{i t}$ & Number of population covered by license $i$ \\
\hline$N A S D A Q_{t}$ & Monthly close of NASDAQ at time $t$ \\
\hline$G G G_{i}$ & $\begin{array}{l}\text { Dummy Variable }=1 \text { for } 3 \mathrm{G} \text { auction or IMT-2000, } 0 \\
\text { otherwise }\end{array}$ \\
\hline$M H z_{i}$ & $\begin{array}{l}\text { Dummy Variable }=1 \text { if license } i \text { includes } 800 \text { or } 900 \mathrm{MHz} \\
\text { spectrum, } 0 \text { otherwise }\end{array}$ \\
\hline$L I B_{j}$ & $\begin{array}{l}\text { Dummy Variable }=1 \text { for Australia, Guatemala, El Salvador } \\
\text { and New Zealand, } 0 \text { otherwise }\end{array}$ \\
\hline TERM $_{i}$ & License period (year) \\
\hline$\overline{A U C T_{i}}$ & $\begin{array}{l}\text { Dummy variable representing auction type. Dummy } \\
\text { variable }=1 \text { if the auction is first-price sealed-bid auction, } 0 \\
\text { otherwise }\end{array}$ \\
\hline$I_{N C U M_{j t}}$ & $\begin{array}{l}\text { Dummy variable representing characteristics of operators } \\
\text { in the country. Dummy variable }=1 \text { if the winner of auction } \\
\text { is an incumbent, } 0 \text { otherwise }\end{array}$ \\
\hline$U R B_{j t}$ & Level of urbanization in the year of auction \\
\hline$D E N S E_{i j}$ & $\begin{array}{l}\text { Population density per square kilometer in the year of } \\
\text { auction }\end{array}$ \\
\hline$\overline{F C A L L_{j t}}$ & $\begin{array}{l}\text { Mean value of 3-minute residential local call (peak) during } \\
\text { time } t-1 \text { and } t+1\end{array}$ \\
\hline$F C O N N_{j t}$ & Mean value of service fee of residential fixed line \\
\hline$L E G A L_{j}$ & $\begin{array}{l}\text { Discrete variable which indicating level of mobile market } \\
\text { liberalization ranging between } 1 \text { and } 10 \text {. A higher number } \\
\text { means higher barriers }\end{array}$ \\
\hline$U S A_{j}$ & Dummy variable $=1$ if auction is in the US, 0 otherwise \\
\hline
\end{tabular}

NASDAQ has a positive impact on spectrum value as well Since, in general, a stock index is a leading indicator of economic condition. The increasing index implies that the economy is growing. As a result, the demand for telecommunication service and spectrum value increase. In addition, if NASDAQ rises, operators can get funding easily via the stock market reducing their investment costs. When the business profit increases, the spectrum value increases as well.

A technology type of a license (GGG) also has an impact on spectrum value. In the literature research by Hazlett (2004) [9] found that if a spectrum license is for $3 \mathrm{G}$ or IMT-2000, the spectrum value will be significantly higher because $3 \mathrm{G}$ spectrum not only improve the quality of service, but also expand the service coverage.

Furthermore, a first-price seal-bid auction (AUCT) also significantly and positively influences the spectrum value. The first-price sealed-bid auction trends to generate higher revenue than auction formats, especially if bidders have no experience on spectrum auction.

Therefore, the fact that an incumbent wins can also affect the spectrum value. This research [9] found that if an incumbent wins, the spectrum value will increase significantly because the incumbent can use the new spectrum as a complement of the existing services to increase its income. In additional, it will also create a barrier on potential new entrants both in terms of marketing and costs. Therefore, incumbents tend to bid more aggressively. In addition, a free market economy (LEGAL) partially increases 
the spectrum value since the operators are ensured that their rights to use spectrum will not be intervened by the government. This will result in higher demand for spectrum.

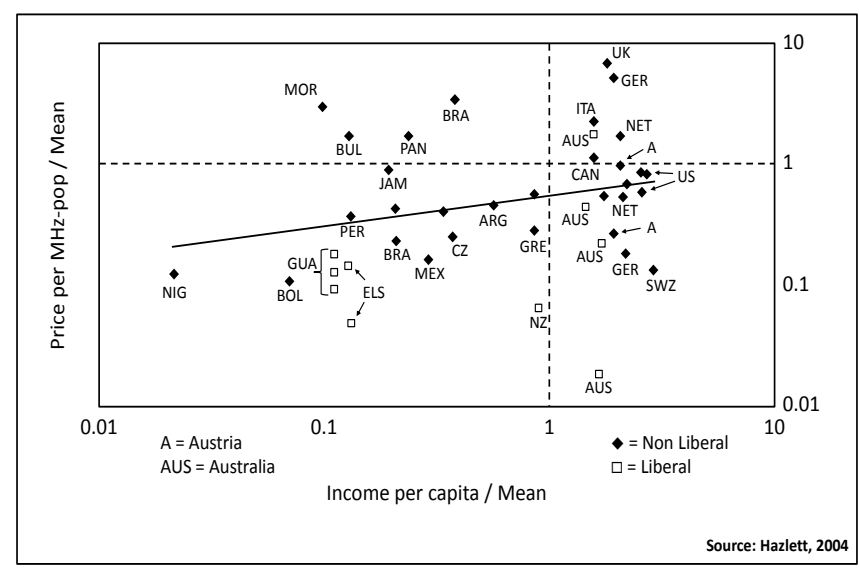

Fig. 2. Average license value to income per capita.

Not only will the exclusive right to use spectrum increase spectrum value, but the policy to liberalize telecommunication industry (LIB variable) is another important determinant of spectrum price in many countries as well. Fig. 2 shows the role of telecommunication market liberalization policy as a relationship between demand for telecommunication service (income per capita) and spectrum value. According to the figure, the spectrum value is on average correlated with income per capita. However, there are a few cases where the income per capita and the spectrum value have an opposite relationship. Countries on the top left group of the figure are Brazil, Morocco and Bulgaria, which have lower-than-average income per capita, but the spectrum value are high. The telecommunication markets in these countries are fairly concentrated. Further, [9] found that the said countries had policies to encourage telecommunication services and thus the spectrum value became higher [9]. In other developing countries such as Guatemala and El Salvador, the income per capita and spectrum value have a positive relationship because their telecommunication market liberalizations increase the competition so that the economic rent of spectrum licenses and the spectrum value became smaller. Thus, the research included LIB in the spectrum valuation model.

\section{B. Spectrum Valuation by Censored Regression}

Apart from ordinary least squares, there are other econometric models that are suitable for spectrum valuation such as censored regression.

Madden, Saglam and Morey (2010) applies censored regression for $3 \mathrm{G}$ spectrum valuation using data from auctions for 81 licenses in 23 countries during 2000 to 2007 [10]. The motivation for censored regression model is that data of spectrum price operators pay is imperfect. Spectrum value measured by auction price reflects that the net gain from spectrum is higher than the reserve price. However, some bidders might values spectrum below the winning price. These values would be recorded as zero but they are actually positive and lower than the winning price. The auction price are therefore inaccurately recorded as they are censored (censored sample). Thus, the censored regression model along with the maximum likelihood estimation are used to deal with such problem.

To construct censored regression model, this research [11] categorized determinants of spectrum value (price/MHz/pop) into five groups as shown in Table III below: variables that reflects economic condition and mobile market characteristics, license characteristics [11], financial obligation, service obligation and auction procedure.

TABLE III: DETERMINANTS OF SPECTRUM VALUE IN STUDY OF [11]

\begin{tabular}{|c|c|c|}
\hline Key variables group & Variable & Description \\
\hline \multirow{4}{*}{$\begin{array}{l}\text { Economic condition } \\
\text { and mobile market } \\
\text { characteristics }\end{array}$} & Income & $\begin{array}{l}\text { Real income per capita (US Dollar in } \\
\text { PPP) }\end{array}$ \\
\hline & Market & $\begin{array}{l}\text { Population in coverage area of } \\
\text { spectrum license (million) }\end{array}$ \\
\hline & Mcomp & $\begin{array}{l}\text { Reciprocal of one plus the number of } \\
\text { operators }\end{array}$ \\
\hline & $\begin{array}{l}\begin{array}{l}\text { Shift } \\
\text { (Dummy) }\end{array} \\
\end{array}$ & $\begin{array}{l}\text { Equal to one if auction took place } \\
\text { during } 2001 \text { to } 2007 \text {, zero otherwise }\end{array}$ \\
\hline \multirow{3}{*}{$\begin{array}{l}\text { License } \\
\text { characteristics }\end{array}$} & Duration & License period (year) \\
\hline & $\begin{array}{l}\text { Entrant } \\
\text { (Dummy) }\end{array}$ & $\begin{array}{l}\text { Equal to one if auctions rule stipulates } \\
\text { that at least one license is set-aside for } \\
\text { operator who has never received } \\
\text { spectrum license, zero otherwise }\end{array}$ \\
\hline & Reserve & Reserve price (US dollar) \\
\hline $\begin{array}{l}\text { Financial } \\
\text { commitment after } \\
\text { winning the auction }\end{array}$ & Percent & $\begin{array}{l}\text { Means of annual fee (percent of income } \\
\text { from using } 3 G \text { spectrum) }\end{array}$ \\
\hline \multirow{2}{*}{$\begin{array}{l}\text { Service obligation } \\
\text { after winning the } \\
\text { auction }\end{array}$} & Deploy & $\begin{array}{l}\text { Percent of population in accordance } \\
\text { with coverage obligation }\end{array}$ \\
\hline & $\begin{array}{l}\begin{array}{l}\text { Share } \\
\text { (Dummy) }\end{array} \\
\end{array}$ & $\begin{array}{l}\text { Equal to one if infrastructure sharing is } \\
\text { mandated }\end{array}$ \\
\hline \multirow[t]{6}{*}{ Auction procedure } & Accomp & $\begin{array}{l}\text { Ratio of the number of bidders to the } \\
\text { number of license }\end{array}$ \\
\hline & $\begin{array}{l}\text { Activity } \\
\text { (Dummy) }\end{array}$ & $\begin{array}{l}\text { Equal to one if auction has activity rule, } \\
\text { zero otherwise }\end{array}$ \\
\hline & $\begin{array}{l}\text { Info } \\
\text { (Dummy) }\end{array}$ & $\begin{array}{l}\text { Equal to one if auction information are } \\
\text { disclosed to the public, } 0 \text { otherwise }\end{array}$ \\
\hline & $\begin{array}{l}\text { Number } \\
\text { (Dummy) }\end{array}$ & $\begin{array}{l}\text { Equal to one if the number of license is } \\
\text { predetermined, zero otherwise }\end{array}$ \\
\hline & $\begin{array}{l}\text { Package } \\
\text { (Dummy) }\end{array}$ & $\begin{array}{l}\text { Equal to one if package bidding is } \\
\text { permitted, zero otherwise }\end{array}$ \\
\hline & $\begin{array}{l}\text { Sealed } \\
\text { (Dummy) }\end{array}$ & $\begin{array}{l}\text { Equal to one if auction is a sealed-bid } \\
\text { format, zero otherwise }\end{array}$ \\
\hline
\end{tabular}

Source: Madden, Saglam and Morey (2010)

Most variables on economic condition and mobile market characteristics have significant impact on spectrum value. The study found that the auction price will be higher if the population coverage of the spectrum license increases. This result is consistent with [10] who conducted a theoretical study from both engineering and economic perspectives, and empirical study to test the result using the data from spectrum auctions in Europe. It found that in theory, important determinants are spectrum demand represented by traffic and spectrum supply represented by bandwidth. In the empirical research, it found that the key determinants of spectrum value are the number of populations (users). However, the spectrum value has a nonlinear relationship with the number of populations. In addition, the income per capita also has a positive impact on spectrum price.

In the license characteristics group of variables, the license period and the reserve price are two factors that have significant impact on spectrum value. These two variables have a positive impact on spectrum value. The findings are consistent with Klemperer (2002b) and Cramton (2002) and which found that the sufficiently high reserve price prevents 
bidder collusion, which keeps the auction price low [12], [13].

The variable entrant has no effect on spectrum price as expected. The set-aside spectrum for new entrants should actually increase the number of bidders and so that the spectrum value increases. However, the estimation result shows an insignificant effect.

The group of financial commitment variables, namely annual fee (percentage of income from $3 \mathrm{G}$ service), also has insignificant impact on spectrum value. It implies that the operators do not consider this variable in their bidding decision.

For the factors on service commitment after winning the auction, The research in [11] found that no variable in the group (both Deploy and Share) affects spectrum value, unlike the assumptions made. The service deployment in accordance with coverage obligation (Deploy) was expected to be an important factor in explaining the spectrum value because if the service deployment is able to serve the demand within the coverage area (Deploy variable increase), the operator's profit should also increase. This increases spectrum value. However, the Deploy variable is insignificant perhaps because the coverage obligation on deployment of service area is not beneficial to the operators as they already have sufficient service coverage.

The share variable is not statistically significance because of two conflicting reasons. According to Binmore and Klemperer (2002), the obligation that mandate infrastructure sharing would lower the costs of incumbents who have $2 \mathrm{G}$ licenses [14]. This gives incumbents some advantage over new operators. Therefore, the incumbents bid more aggressively in the auction. In contrast, a license that mandates infrastructure sharing reduces profits from incumbent's point of view and thus decreases the spectrum value. As a result, these two conflicting reasons might explain why the Share variable is statistically insignificant.

The final group of variables relates to auction procedure. Madden, Saglam and Morey (2010) found them mostly significant in explaining spectrum value [11]. The Accomp variable or the ratio of the number of bidders to the number of licenses has a positive effect on spectrum value consistent with Klemperer (2002b) [15]. The higher ratio leads to more auction competition and higher spectrum value.

The Activity dummy variable which is a part of auction rule (Activity Rule) has a negative impact. It implies that the auction rules that limit frequency blocks or packages might reduce competition between competing bidders.

The Info variable is a dummy for public information disclosure including the number of bidders and auction value. The study found that it has a positive relationship as expected because the disclosure in each auction round will deter bidder collusion. In addition, the Number variable has a large and negative impact on auction value since it increase the competition in the auction.

The Sealed variable which is a dummy for sealed-bid auction has insignificant impact on spectrum value because the sealed-bid auction might either increase or decrease the spectrum value. [15] said that the Sealed-bid auction might prevent bidders from signaling which help increase competition and the auction price. In contrast, the open auction might decrease the auction value in case that bidders are afraid of overbidding.

Nevertheless the research by Bohlin, Madden and Morey (2010) conducted spectrum valuation of $3 \mathrm{G}$ spectrum [16]. Following Madden, Saglam and Morey (2010), it used similar censored regression model but it added more variable such as average auction price, dummy variable for Asian countries, auction deposit and time limit for coverage obligation [11].

Among the additional variables, the average auction price is an independent variable that might create endogeneity problem with the dependent variable (spectrum value per $\mathrm{MHz}$ per population). Hence, the research [16], employed two-stage least squares to solve such problem. At first stage, it estimates the equation by least squares with average auction value as the dependent variable and independent variables including ratio of the number of bidders to the number of licenses (Accomp), population density (Density), income per capita and Shift dummy for auctions from 2000 to 2001. According to the result of the initial estimation, Bohlin, Madden and Morey (2010) found that the factors that have significant influences on the average auction price are Accomp, Income and Shift. Shift has a positive effect whereas the Accomp has an opposite effect on the average auction price [16].

After estimation of equation, this research suggests that [16] forecasted average auction price and replace the existing endogenous average auction price with the fitted values. After estimating the model parameters, it is found that the average auction price has a positive and significant effect on spectrum value per $\mathrm{MHz}$ per capita. Furthermore, among the additional variables, significant determinants of the spectrum value are Asia, Deposit and Time. All these variables have positive relationship with the spectrum value.

When comparing the estimation result with [11], it is found that the estimation result is consistent except Share (infrastructures sharing). In contrast, [16] found its significance and positive effect to the spectrum value. This result supports the idea that infrastructure sharing help operators reduce business operation costs.

In summary, according to the studies of spectrum valuation by censored regression in the past, we can categorize variables that have significant effect on spectrum value and have the relationship as predicted by the theory into three groups: (1) factors concerning spectrum demand, (2) factor concerning spectrum auction characteristics and (3) factors concerning pre- and post-auction obligations. Factors concerning spectrum demand are variables that reflect the size of the economy and the needs for spectrum. This group includes country's income, the number of populations, and the time when telecommunication market was booming. The group of factors concerning spectrum auction characteristics will express the level of competition in spectrum auction, including the number of bidders per license offered. The last group of variables includes factors concerning pre- and post-auction obligations. They are important factors to be considered by bidders before entering the auction. These include reservation of license for next auction, amount of deposit to be made before auction, annual fee and coverage obligation.

The summary of factors with significant influence to spectrum value from studies by censored regression and 
ordinary least squares are shown in Table IV.

TABLE IV: SUMMARY OF DETERMINANTS OF SPECTRUM VALUE FROM ECONOMETRIC STUDIES

\begin{tabular}{|c|c|c|}
\hline \multicolumn{3}{|c|}{ Determinants of spectrum value } \\
\hline Demand side & Auction characteristics & $\begin{array}{c}\text { Pre and post-auction } \\
\text { obligations }\end{array}$ \\
\hline Country income & $\begin{array}{l}\text { Number of bidders per } \\
\text { license }\end{array}$ & $\begin{array}{l}\text { Reservation of licenses } \\
\text { for next auction }\end{array}$ \\
\hline Income per capita & Number of licenses & $\begin{array}{l}\text { Auction deposit } \\
\text { amount }\end{array}$ \\
\hline Number of populations & Sealed-bid auction type & Annual fee \\
\hline Level of urbanization & Winner is an incumbent & Coverage obligation \\
\hline $\begin{array}{l}\text { Period of time when } \\
\text { telecommunication is } \\
\text { booming }\end{array}$ & \multirow[t]{2}{*}{$\begin{array}{l}\text { Level of competition in } \\
\text { telecommunication } \\
\text { market }\end{array}$} & \\
\hline Stock index & & \\
\hline
\end{tabular}

Table IV summarize determinants of spectrum value from studies using econometric method. Information from the table will be used as a framework in selecting regression variables for spectrum valuation by econometrics.

\section{CONCLUSION}

These are useful estimation tools that economists have developed for spectrum estimation, yet there is no right or wrong approach for estimation of spectrum value. From a variety of aforementioned modeling approaches for spectrum value estimation, the econometric approach is the most popular. This is firstly due to the fact that the econometric approach utilizes the real past data instead of using the forecast data, which has high level of uncertainty. Secondly, it is an optimal approach only if there is wide access to historical data. However, if there is no access to business data then econometric approach is not an ideal approach. Thirdly, the econometric approach can easily be adjusted to cope with changes of the factors. Last but not least, the econometric approach has variety of estimation techniques, thus the results can be crosschecked before concluding whether the final spectrum estimation value. Overall, two or three spectrum estimations can be employed to cross check against short comings from each other, in order to ensure spectrum value estimation for the auction is as accurate as possible. This is particularly pertinent as spectrum value estimation is used to conclude on a reserve price of spectrum block for the auction.

\section{REFERENCES}

[1] B. Mölleryd and J. Markendahl, "Valuation of spectrum for mobile broadband services-the case of Sweden and India," in Proc. ITS India Conference, 2012.

[2] B. G. Mölleryd, J. Markendahl, and Ö. Mäkitalo, "Spectrum valuation derived from network deployment and strategic positioning with different levels of spectrum in $800 \mathrm{MHz}, "$ in Proc. 8th Biennial and Silver Anniversary ITS Conference, Tokyo, 2010.

[3] C. Bazelon, "The economic basis of spectrum value: Pairing AWS-3 with the $1755 \mathrm{MHz}$ band is more valuable than pairing it with frequencies from the $1690 \mathrm{MHz}$ band," The Brattle Group, Washington DC, 2011.

[4] PlumConsulting, Valuation of Public Mobile Spectrum at 825-845 $\mathrm{MHz}$ and 870-890 MHz, London, 2011.

[5] PlumConsulting, Methodologies for Valuing Spectrum: Review of Experts' Report, 2011.
[6] P. Marks, K. Pearson, B. Williamson, P. Hansell, and J. Burns. (2009) Estimating the commercial trading value of spectrum. A Ofcom Report by Plum Consulting. [Online]. Available: www.plumconsulting.co.uk/pdfs/Plum_July09_Commercial_trading_ value_of_spectrum.pdf

[7] T. R. Beard, G. S. Ford, L. J. Spiwak, and M. L. Stern, "A policy framework for spectrum allocation in mobile communications," Federal Communications Law Journal, vol. 62, p. 630, 2010.

[8] P. Marks, K. Pearson, B. Williamson, P. Hansell, and J. Burns, Estimating the Commercial Trading Value of Spectrum, 2009.

[9] T. W. Hazlett, "Property rights and wireless license values," Manhattan Institute for Policy Research, Columbia Institute for Tele-Information, Telecommunications Union, 2004.

[10] G. Madden, I. Sağlam, and A. Morey, "Auction design and the success of national $3 \mathrm{G}$ spectrum auctions," TÜSİAD-Koç University Economic Research Forum working Paper Series, 2010.

[11] G. Madden, I. Sağlam, and A. Morey, Auction Design and the Success of National 3 G Spectrum Auctions, 2010.

[12] P. Klemperer, "What really Matters in auction design," The Journal of Economic Perspectives, vol. 16, pp. 169-189, 2002.

[13] P. Cramton, Spectrum auctions, 2002.

[14] K. Binmore and P. Klemperer, "The biggest auction ever: The sale of the British 3G telecom licences," The Economic Journal, vol. 112, pp. C74-C96, 2002.

[15] P. Klemperer, "How (not) to run auctions: The European $3 \mathrm{G}$ telecom auctions," European Economic Review, vol. 46, pp. 829-845, 2002.

[16] E. Bohlin, G. G. Madden, and A. Morey, "An econometric analysis of 3G auction spectrum valuations," European University Institute, 2010.

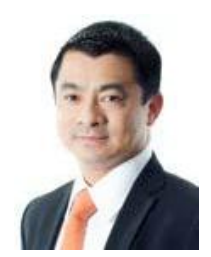

Settapong Malisuwan was born on March 24, 1966 in Bangkok, Thailand. He was awarded a full scholarship from Thai government for the $\mathrm{PhD}$ in electrical engineering (telecommunications), specializing in mobile communication systems from Florida Atlantic University, Boca Raton in 2000. He received his MSc in electrical engineering in mobile communications system from George Washington University in 1996 and was awarded the First Class Honors, Gold Medal Award and Outstanding Cadet Award by the university. He also achieved the MSc in electrical engineering in telecommunication engineering from Georgia Institute of Technology in 1992. Furthermore, he achieved the military education from Special Warfare Center, Thailand, specializing in Ranger and Airborne Courses in 1989 and 1988 respectively. He is currently the vice chairman and a board commissioner of National Broadcasting and Telecommunications Regulator in Bangkok, Thailand. He was awarded The "Science Towards the Excellence in 2013" by The Senate Standing Committee on Science, Technology, Communications and Telecommunications. His research interests are in electromagnetics, efficient spectrum management and Telecommunications policy and management.

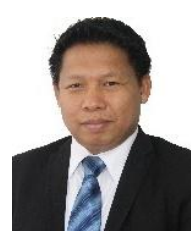

Noppadol Tiamnara was born November 12, 1968 in Pah Na Korn Sri Ayuttaya, Thailand. He received the degree diploma of Vocational education in industrial technology from South-East Asia Colledge, Thailand, 1990, and the bachelor degree of Electrical engineering from Saint John's University, Thailand, 2002. He received the master degree of science in technology management from Thammasart University, Thailand in 2012. Since 2006, he has been working in National Broadcasting and Telecommunications Commission as an assistant for secretary of vice chairman of National Broadcasting and Telecommunication Commission (NBTC). His research interests include LTE design, wireless systems, microstrip antenna and applied electromagnetic.

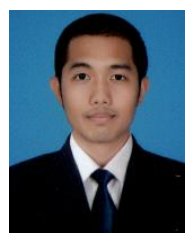

Nattakit Suriyakrai was born in Khonkhaen, Thailand on March 22, 1987. He received his bachelor of liberal arts in Japanese language from Thammasat University in 2010. He has been working as an assistant for the vice chairman in national broadcasting and telecommunications, Bangkok, Thailand since November 2012. His research interests are technology management and spectrum management. 